\title{
THE GRAMMATICAL ERRORS ON THE PARAGRAPH WRITINGS
}

\author{
Nadiah Ma'mun \\ UIN Walisongo Semarang \\ nadiahmamun@gmail.com
}

\begin{abstract}
This paper makes a study of grammatical error on paragraph writings of English department students. The students were asked to write the paragraph of writing as their final assignment for paragraph based writing Class. The errors found in the students' compositions are then classified based on the surface strategy taxonomy on errors of omission, addition, misformation, and misordering. Based on the result of the research findings whole have been analyzed and the discussions which have been presented, the writer generally concluded that there are four kinds of errors which are omission, addition, misinformation and misordering. The writer found that mostly the students had grammatical error on their writing in misinformation error $43 \%$. They consist of misinformation of adverb, V2, subject-verb agreement, article, modal, passive and word choices. It also can be concluded that most students of intermediate level made Grammatical Error in Omission and Misinformation of their paragraph writing as Dulaay at.all (1982) said that Omission of to be is common error made by students. Even tough those sentences appear without to be, article or preposition and still have meaning, student must use the Grammar correctly or accurately in writing. Most students made grammatical error in using modal, for example of error in misinformatiom "We can learning all about English, after modal must be followed by main verb. It mostly happened on students' writing.

The most common types of errors made by students are misinformation with the number of errors is 15 or $43 \%$ and o mis sion with the number of error is 11 or $31 \%$. The type of errors with the lowest frequency is misordering errors $(9 \%)$. They consist of misordering of noun phrase and misordering of adverb. These errors seem to be caused by interlingual and intralingual interference.
\end{abstract}

Key words : paragraph writing and grammatical error 


\section{Introduction}

Learning a language is the same with learning its structure. Groups of words have little or no meanings if they are not ordered in a way recognizable to the listener or reader. Freeman (2001:8) says that "if you knew all the rules in all grammar books around the world but couldn't use them, you wouldn't have learned what you needed to in order to become a fluent speaker." All languages have structure.

Grammar is an important and necessary skill that a student must have (Gunn and McCallum, 2005:41). It becomes unimportant if the student can not use it accurately in communication. A learner of English needs to learn grammar and use it correctly. Ellis (2006:6) says that in learning grammar, learners face two difficulties i.e, the difficulty in understanding a grammatical rules/features and the difficulty in internalizing grammatical features so that they are able to use them correctly. Learners' grammatical errors were of no significance at all in the pre-scientific era when language teachers concentrated their efforts on the language by the learners. It came of no avail to make much fuss about errors as the belief generally held at that time among teachers and linguists was that it was teaching methodology that should be improved if learners made errors. It was considered that bad teaching probably gave rise to errors by learners, and if the teaching methodology improved to perfection, errors would be avoided and the learners would be enabled to learn that pure and accurate form of the target language.

Another attitude towards learners' grammatical errors was that errors were simply inevitable in the learning process and what counted most was to design some methodology with such errors. Accordingly, there would be no need to identify the sources of errors or the possibility of giving learners' errors their own right as a system. At the time when contrastive analysis prevailed in the field of applied linguistics and learners errors were identified as the interference of the mother tongue of the learner with the target language they were learning itself.

The researcher observes the paragraph writings of English department students in paragraph based writing course she teaches. 
She found out many mistakes in them. For example; Every morning I woke up at 4 a.m, then I tidied my room. After tidying up the room, I shower and go to campus. The first underline the student should change the tense to be present. The reason is the time signal of daily activity should use present. And the second underline, the student omits verb before shower, the student should put verb after subject, e.g; I take a shower or I take a bath.

And there are some other examples give us an error sentences (grammatical errors in paragraph writing). Writing can be difficult even in our own language, in a new language, writing can be even more difficult. In the fact many grammatical errors are found in their paragraphs they wrote. The grammatical errors are usually found by the researcher in the students writing that Grammatical errors make the writer interested to research.

According to Corder (1967:23), Error Analysis has two objects: one theoretical and another applied. The theoretical object is to understand what and how a learner learns when he studies an L2. The applied object is to enable the learner to learn more efficiently by using the knowledge of his dialect for pedagogical purposes. At the same time, the investigation of errors can serve two purposes, diagnostic (to in-point the problem) and prognostic (to make plans to solve a problem). Corder (1967:26) said that it is diagnostic because it can tell us the learner's grasp of a language at any given point during the learning process. It is also prognostic because it can tell the teacher to modify learning materials to meet the learners' problems.

\section{Background Literature}

In order to communicate well both written and speech, learners should learn the rules of a language. A learner cannot avoid errors because errors mostly and naturally occur in learning process. It happens because the learner uses different forms to deliver their ideas, feeling, or messages. Vildomec (in Richard 1974: 8) observes that interference between the bilingual's languages is generally on the productive rather than receptive side. It is important that students know how to identify an error in order to avoid it in the future. 


\section{Error Analysis}

The main focus of Contrastive analysis (CA) was on comparing the mother tongue (MT) and the target language (TL) in order to predict or explain the errors made by learners. Therefore errors were considered as being the result of the persistence of existing mother tongue habits the new language (Vecide Erdogan : 262 ). Vecide Erdogan states in his journal that Error Analysis (EA) appeared in the sixties to demonstrate that learner errors were not only because of the learners' native language but also they reflected some universal learning strategies. According to him, -EA deals with the learners" performance in terms of the cognitive process they make use of in recognizing or coding the input they receive from the target language. Therefore, a primary focus of EA is on the evidence that learners' errors provide with an understanding of the underlying process of second language acquisition.

Dulay, et al have in line idea such the opinion above that, - The EA movement can be characterized as an attempt to account for learner errors that could not be explained or predicted by CA or behaviorist theory, and to bring the field of applied linguistics into step which current climate of theoretical opinion (Heidi Dulay, et al., 1982, 141) can be summed up that EA emerged to change the place of CA perception about learner's errors which the CA was affected by behaviorist theory.

Some experts give their opinions about EA. According to Gass and linker EA is a type of linguistic analysis that focuses on the errors learners make. EA compares between the errors a learner makes in producing the TL and the TL form itself. They explain that, -Error analysis provides a broader range of possible explanations than contrastive analysis for researchers/teachers to use to account for errors, as the latter only attributed errors to the NL -Native Language (by the writer) - (Taylor \& Francis, 2008 : 102-103). It means that EA which concerns in learners' error can explain more about learner's error what CA can't predict.

While Ellis and Barkhuizen further explain that -Error Analysis (EA) consits of a set of procedures for identifying, describing, and explaining learner's errors (Rod Ellis and Gary Barkhui- 
zen, Analysing Learner Langaue :2008, 51). Gorbet also explains that, -The basic task of error analysis is to describe how learning occurs by examining the learner's =output (Frances Gorbet, English Language Teaching Journal, XXXIV, 1979, p. 24). James furthermore argues that, -Error analysis is the process of determining the incidence, nature, causes and consequences of unsuccessful language (Carl James, Errors in Language Learning and Use: Exploring Error Analysis,1998, p.1). It seems that the use EA is such a tool that investigates student's learning process in acquiring second language by identifying, describing, analyzing, and explaining the learner's error.

It can be concluded that the presence of EA was to explain what CA cannot predict about learners' error. CA considered error as interference of mother tongue affected by behaviorist theory and lasting until late sixties. EA which regarded error was not only because of the learner's native language but also it reflected some universal learning strategies, is as a tool to investigate the learner's error in acquiring language which consists of identifying, describing, analyzing, and explaining the errors.

\section{Error and Mistake}

Some people have overlapping perception between Error and Mistake, so some teachers. Then further dealing with Error and Mistake becomes inappropriate treated and then it gives negative impact to the students to know and to measure their competence in language learning process. Therefore, a systematic elaboration of the distinction between Error and Mistake is necessary in order to have sound explanation.

Inevitably the learner will make Mistakes and Errors in the language acquisition process. As Dulay hints that, -Making error is an inevitable part of learning. People cannot learn language without first systematically committing errors (Dulay : 138). Brown also states that, -Learning is fundamentally a process that involves the making of mistakes. Mistakes, misjudgments, miscalculation, and erroneous assumptions form an important aspect of learning virtually and skill or acquiring information. It means that making Mis- 
takes and Error is naturally happened for learner because it is a part of learning in language acquisition process.

Further Brown distinguishes between Mistake and Error. He explains that: A mistake refers to a performance error that is either a random guess or a slip', in that it is a failure to utilize a known system correctly. All people make mistakes, in both native and second language situations. Native speakers are normally capable of recognizing and correcting such -lapses or mistakes, which are not the result of a deficiency in competence but the result of some sort of temporary breakdown or imperfection in the process of producing speech. An error is a noticeable deviation from the adult grammar of a native speaker, reflecting the competence of the learner.

It means that Error reveals the learner's knowledge of the target language, while Mistake is the learner's temporary impediment or imperfection in process of utilizing the language. Corder in LarsenFreeman and Long give more explanation about Error and Mistake.

Corder made a distinction between a mistake and an error, i.e.: Whereas a mistake is a random performance slip caused by fatigue, excitement, etc, and therefore can be readily self-corrected, an error is a systematic deviation made by learners who have not yet mastered the rules of the L2. A learner cannot self-corrected an error because it is a product reflective of his or her current stage of development, or underlying competence. Rather than being seen as something to be prevented, then errors were signs that learners were actively engaged in hypothesis testing which would ultimately in the acquisition of TL rules (Diane Larsen-Freeman and Michael H. Long, An Introduction to Second Language Acquisition Research, 58-59).

It can be concluded that Mistake is related to the students quality performance caused by some factors such as fatigue, lack of attention and motivation, carelessness and some other factors but it can be self-corrected because actually the students know the language's rule when they focus on Error. Student's deficiency competence, it means that students don't know about the knowledge of the language at all because they have not mastered it yet therefore it can't be self-corrected. The explanation above can be summarized in the table below. 
The Grammatical Errors on The Paragraph Writings

Table 2.1

The Distinction between Error and Mistake

\begin{tabular}{|c|c|}
\hline Mistake & Error \\
\hline $\begin{array}{c}\text { Related to the students' quality } \\
\text { performance. }\end{array}$ & $\begin{array}{c}\text { Related to the students' deficiency } \\
\text { competence. }\end{array}$ \\
\hline $\begin{array}{c}\text { Can be self-corrected when } \\
\text { the students pay attention. }\end{array}$ & $\begin{array}{c}\text { Cannot be self-corrected because } \\
\text { the students do not know the cor- } \\
\text { rect of the TL rules. }\end{array}$ \\
\hline $\begin{array}{c}\text { Inconsistent deviation. } \\
\text { Caused by some factors such as fa- } \\
\text { tigue, lack of attention and motiva- } \\
\text { tion, carelessness, etc. }\end{array}$ & $\begin{array}{c}\text { Caused by learners who have not } \\
\text { mastered yet the TL rules. }\end{array}$ \\
\hline $\begin{array}{c}\text { Reflected the students' temporary } \\
\text { impediment or imperfection when } \\
\text { utilizing the TL. }\end{array}$ & $\begin{array}{c}\text { Reflected the students' understand- } \\
\text { ing or competency in the target } \\
\text { language. }\end{array}$ \\
\hline
\end{tabular}

Grammar error analysis is aimed to make the students' writing more intelligible and ideas of the writing clearer. James (1980:5) adds that error analysis gives progress towards the mastery of the foreign language.

Human learning is fundamentally a process that involves making of error and mistake assumptions that form an important aspect of learning virtually any skill or acquiring information. Dullay (1982:138) defines errors as the flawed sine of learner speech or writing. They are those parts of conversation or composition that delicate from some selected norm of mature language performance.

This explanation says that there is something wrong in the norms of language performance; making of errors is unavoidable in the learning process. Besides, making of error is one of part of learning and no one can learn without making errors.

Corder (1981:10-11) says that errors can give suggestions to the teachers because errors can be the sign of the successful of learning 
process. In other hand, error also can be the fact of the researcher about the research which is done by her. The errors also can be benchmarks to the students how well they know about languages.

Meanwhile, Brown (2000:170) states that errors as a noticeable deviation from the adult grammar of a native speaker, reflecting the interlanguage competence the interlanguage competence of the learner. Every learner has different competence of level in learning English and it conduct that they have different type of error. For example if learner asks: "do you can drink coffee?' they are probably reflecting a competence in which all verbs require a pre-posed do auxiliary for question formation. So he has committed an error.

On other hand, Harmer (1983:35) says that errors are the result of incorrect rule learning; language has been stored in the brain incorrectly. The errors may happen in the teaching learning process, may be it is caused by teacher, they have the lack of grammar competences in English teaching or by the students who have different understanding or wrong perception then they save on the brain for long time and improve in their English grammar.

According to Corder (1967:55) learner errors are significant in the ways: (1) they serve a learning purpose by showing teachers what learner have learned and what they have not yet mastered. (2) They serve a research purpose by providing evidence how languages are learned. (3) They serve a learning purpose by acting as devices by what learner discover the rule of target languages. (Rod Ellis: 2008: 51).

Following Corder (1974:55), we can distinguish the following steps in conducting an Error analysis: collecting of a sample of leaning language, identification of errors, Describing of errors, explaining of errors and error evaluation.

We may also think about mistake if we talk about error. It is because error and mistake are not the same; it is crucial to make distinction about definition of both. Harmer (1983:35) states that mistake is less serious since it is the retrieval that is faulty not the knowledge. Brown (2000:170) also states that a mistake refers to a performance error that is either a random guess or a slip. People make mistake in both native and second language situation. 
Hubbard (1983:134) states that errors caused by lack of knowledge about the target language or by incorrect hypotheses about it; and mistakes caused by temporary lapses of memory, confusion, slips of tongue and so on. In conclusion, if the learners can correct by themselves, it is probably mistake, but if they cannot, it is an error.

The fact that learners do make errors and these errors can be observed, analyzed, and classified to reveal something or the system operating with in the learners, led to surge of study of learners' errors called error analysis.

\section{The Sources of Error}

According to Brown (1987:177-180), there are three causes of error which are interlangual transfer, intralingual transfer and context of learning.

1. Interlangual transfer

The native language is the only previous linguistic system that the learner can draw upon; thus the interference is inevitable. For example "the book of John" is actually can be said "John's book".

2. Intralingual transfer

One a learner has acquired parts of the new system, more and more intralingual transfer-generalization within target language would occur, for example "Does john can sing".

3. Context of learning

This error can be from the teacher teaching or form the book.

It can be highlighted that Taylor classifies the source of error based on the learners' linguistic development stage. While Brown and James classify the source of error into four main categories, namely: interlingual transfer, intralingual transfer, communication strategy and context of learning or in James called induced error. The writer uses the four main categories sources of error based on Brown's idea to find out the students' sources of error in her research. 


\section{The Causes of Error}

John Norrish exposes three causes of errors:

1. Carelessness: It is often closely related to lack of motivation. Many teachers will admit that it is not always the students' fault if he loses interest; perhaps the materials and/or the style of presentation do not suit him.

2. First language interference: Learning a language (mother tongue or a foreign language) was a matter of habit information. The learners' utterances were thought to be gradually = shaped' towards those of the language he was learning.

3. Translation: Probably the most students make errors is translation.

This happens because a student translates his first language sentence of idiomatic expression in to the target language word by word (John Norrish, 1938 : 21-26).

It can be highlighted that Norrish divides the cause of errors into three categories, those are Carelessness, First Language Interference and Translation which those are from the learners themselves or the teacher, and the method.

\section{The Types of Error}

Dulay, Burt, and Kashen's (1982:150) suggest that there are four principal ways in which learners modify target forms:

1. Omission (for example, omission of copula be in the utterance My sisters very pretty)

2. Addition. This is sub-categorized:

a. Regularization (For Example, eated for ate)

b. Double-marking (for example, He didn't came)

c. Simple Addition (not regularization or double-marking)

3. Misinformation (i.e. the use of the wrong from the morpheme or structure)

a. Regularization (for example, do they be happy?)

b. Archi-forms (for example, me speak to me)

c. Alternating form

4. Misordering (for example, she fights all the time her brother) 
The other type of errors is elaborated by Dulay et al who classify error into our descriptive classifications of errors. They are linguistic category, surface strategy taxonomy, comparative taxonomy, and communicative effect taxonomy.

a. Error Types Based on Linguistic Category

These linguistic category taxonomies classify errors according to either or both the language component or the particular linguistic constituent the errors effects. Language components include the phonology (pronunciation), syntax and morphology (grammar), semantic and lexicon (meaning and vocabulary), and discourse (style). Constituents include the elements that comprise each language component. For example, within syntax one may ask whether the error is in the main or subordinate clause; and within a clause, which constituent is affected, e.g. the noun phrase, the auxiliary, the verb phrase, the preposition, the adverb, the adjectives, and so forth (Dulay : $146-147)$.

\section{Table 2.2 A Sample Linguistic Category Taxonomy}

\begin{tabular}{|c|c|c|c|}
\hline No. & $\begin{array}{c}\text { Linguistic Category and } \\
\text { Error Type }\end{array}$ & $\begin{array}{c}\text { Example of } \\
\text { Learner } \\
\text { Error }\end{array}$ & Explanation \\
\hline 1. & 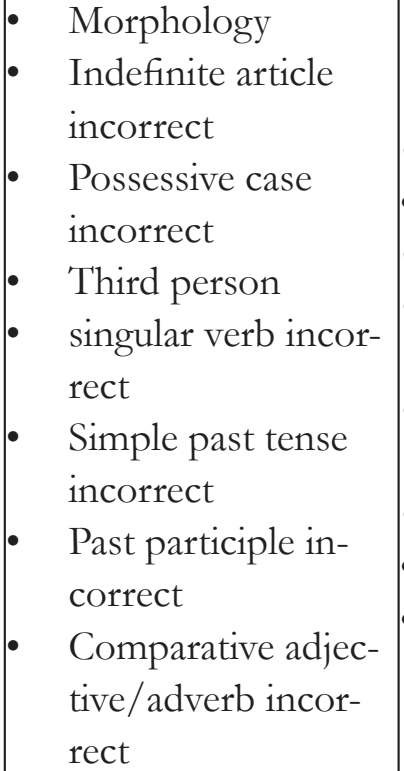 & $\begin{array}{l}\text { - } A \text { ant } \\
\text { - } \text { The man feet } \\
\text { The bird help } \\
\text { man. } \\
\text { He putted the } \\
\text { cookie there. } \\
\text { He was call. } \\
\text { He got up } \\
\text { more higher. }\end{array}$ & 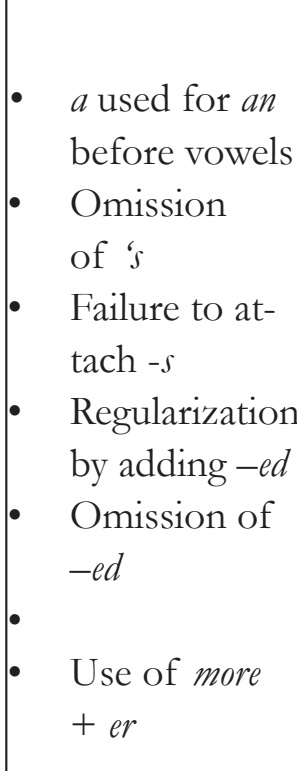 \\
\hline
\end{tabular}




\begin{tabular}{|c|c|c|c|}
\hline No. & $\begin{array}{c}\text { Linguistic Category and } \\
\text { Error Type }\end{array}$ & $\begin{array}{c}\text { Example of } \\
\text { Learner } \\
\text { Error }\end{array}$ & Explanation \\
\hline 2 & $\begin{array}{ll}\text { - } & \text { Syntax } \\
\text { - } & \text { Voun Phrase } \\
\text { - } & \text { Verb-and-verb Con- } \\
\text { struction } \\
\text { - Word Order } \\
\text { Some transforma- } \\
\text { tions }\end{array}$ & $\begin{array}{l}\text { He put in the } \\
\text { his room } \\
\text { He in water } \\
\text { I go play } \\
\text { The bird } \\
\text { (object) he } \\
\text { was gonna } \\
\text { shoot it. } \\
\text { He not play } \\
\text { anymore }\end{array}$ & $\begin{array}{l}\text { - Use of pos- } \\
\text { sessive and } \\
\text { the article } \\
\text { - Omission of } \\
\text { to be } \\
\text { Omission of } \\
\text { to in identical } \\
\text { subject con- } \\
\text { struction } \\
\text { Repetition of } \\
\text { the object } \\
\text { Formation } \\
\text { of no or not } \\
\text { without the } \\
\text { auxiliary. }\end{array}$ \\
\hline
\end{tabular}

\section{b. Surface Strategy Taxonomy}

Learner may omit necessary any morphemes or words, add unnecessary ones, misform items, or misorder them. Therefore, Dulay et al divide the error based on surface strategy taxonomy into four categories. There are Omission, Addition, Misformation, and Misorder.

\section{Omission}

Omission errors are characterized by the absence of an item that must appear in a well-formed utterance. Content morphemes carry the bulk of the referential meaning of a sentence: Nouns, verbs, adjectives, adverbs. Language learners omit grammatical morphemes much more frequently than content words (Dulay, 154). For example:

a. Mary is the president of the new company.

(1). Mary, president, new, company. (Content Morpheme)

(2). Is, the, of, the. (Grammatical Morpheme) 
c. Marry the president of the new company. (Omission of Grammatical Morpheme 'is')

d. Marry is the president of the new. (Omission of Content Morpheme 'Company')

\section{Addition}

Addition errors are the presence of an item which must not appear in a well-formed utterance. There are three types of addition errors, namely: double marking, regularization, and simple addition.

a) Double Marking

Many addition errors are more accurately described as the failure to delete certain items which are required in some linguistic construction, but not in others. Double marking is two items marked for the same feature. Learners who have acquired the tensed form for both auxiliary and verb often place the marker both, as in; ${ }^{* *} \mathrm{He}$ doesn't knows my name, ${ }^{* *}$ We didn't went there.

Which the correction of the sentence above is; *

He doesn't know my name \& We didn't go there.

b) Regularization

Regularization errors that fall under the addition category are those in which a marker that is typically added to a linguistic item is erroneously added to exceptional items of the given class that do not take a marker.

It means that regularization error occurs when learners add morpheme to the exceptional words, for example: 


\section{Table 2.3 Example of Regularization errors}

$\begin{array}{lll}\text { No. } & \text { Regularization Errors } & \text { Correction } \\ \text { 1. } & \text { Sheeps } & \text { Sheep } \\ \text { 2. } & \text { Putted } & \text { Put } \\ \text { 3. } & \text { Deers } & \text { Deer } \\ \text { 4. } & \text { Hitted } & \text { Hit } \\ \text { 5. } & \text { Beated } & \text { Beat }\end{array}$

c) Simple Addition

No particular features characterize simple additions other than those that characterize all addition errors - the use of an item which should not appear in a well- formed utterance.

Table 2.4 Simple Addition Errors

\begin{tabular}{|c|c|}
\hline Linguistic Item Added & Example \\
\hline Third person singular_s & The fishes does not live in the water \\
\hline Past tense (irregular) & The train is gonna broke it \\
\hline Article $a$ & $a$ this \\
\hline Preposition & in over there \\
\hline
\end{tabular}

3. Misformation

Misformation errors are characterized by the use of the wrong form of the morpheme or structure. In misformation errors the learner supplies something, although it is incorrect. For example: The dog eated the chicken.

There are three types of misformation errors, they are regularization errors, archi-forms, and alternating forms. The explanation is elaborated as follows 
a) Regularization Errors

Regularization errors that fall under the misformation category are those in which a regular marker is used in place of an irregular one, as in runned for ran or gooses for geese.

b) Archi-forms

The selection of one member of a class of forms to represent others in the class is a common characteristic of all stages of second language acquisition. For example;

- Give me that.

- Me hungry.

- That dog.

- That dogs.

c) Alternating Forms

As the learner's vocabulary and grammar grow, the use of archi-forms often gives way to the apparently fairly free alternation of various members of a class with each other. For example;

- Those dog. - I seen her yesterday.

\section{Misoreder}

As the label suggests, misordering errors are characterized by the incorrect placement of a morpheme or group of morphemes in an utterance. For example, in the utterance:

- He is all the time late.

- What Daddy is doing?

- I don't know what is that.

The correct utterances are:

- He is late all the time.

- What is Daddy doing?

- I don't know what that is.

\section{c. Comparative Taxonomy}

The classification of errors in a comparative taxonomy is based on comparisons between the structure of L2 errors and certain other types of constructions. These comparisons have yielded the 
two major errors categories in this taxonomy: developmental errors and interlingual errors. Two other categories that have been used in comparative analysis taxonomies are derived from the first two: ambiguous errors, which are classifiable as either developmental or interlingual; and of course, the grab bag category, other, which are neither.

1) Developmental Errors

Developmental errors are errors similar to those made by children learning that target language as their first language, take for example:

- Dog eat it.

\section{2) Interlingual Errors}

Interlingual errors are similar in structure to a semantically equivalent phrase or sentence in the learner's native language. Interlingual errors simply refer to L2 errors that reflect native language structure, regardless of the internal processes or external conditions that spawned them.

\section{3) Ambiguous Errors}

Ambiguous errors are those that could be classified equally well as developmental or interlingual. That is because these errors reflect the learner's native language structure, and at the same time, they are of the type found in the speech of children acquiring a first language. For example, in the utterance:

- I no have a car.

\section{4) Other Errors}

Few taxonomies are complete without a grab bag for items that don't fit into any other category. For example, in the utterance;

- She do hungry.

Meanwhile, Betty Schrampfer Azar explains the type of errors into fourteen kinds. The explanation is elaborated as follows: 
The Grammatical Errors on The Paragraph Writings

a. Singular-Plural

Number is the form of word to show whether it is singular or plural. Singular number is when a noun denotes one object e.g. I have one pen. Plural number is a noun denotes more than one object e.g. I have two pens. In addition, singular can be identified by putting $a$ or an before noun e.g. I has a bird. Generally, plural nouns can be added by $-s$ (as in friends) or $-e s$ (as in classes) after noun. Moreover, in irregular noun form, plural has various types e.g. child-children, ox-oxen, foot-feet, man-men, wife-wives, etc.

b. Word Form

Word form is the phonological or orthographic sound or appearance of a word that can be used to describe or identify something; the inflected forms of a word can be represented by a stem and a list of inflections to be attached.

It means that word form is the change form of word based on the grammatical rules, for example, beautiful (adjective), beautifully (adverb). The error word form in a sentence e.g. I saw a beautypicture.

c. Word choice (Diction)

Diction will be effective only when the words you choose are appropriate for the audience and purpose, when they convey your message accurately and comfortably. The idea of comfort may seem out of place in connection with diction, but in fact words can sometimes cause the reader to feel uncomfortable.

Word choice is to use the word that suits to the context of utterance, the error in word choice for example in the sentence; I am looking at you.

d. Verb tense

Tense means time. However, it should be pointed out that time in relation to action is a concept that exists in the mind of the speaker, reader, or listener. Tense, in actual usage, refers consistently only to grammatical forms. Often tense and time do not correspond at all. In addition to denoting time relationship, 
the verbs tenses may indicate whether an activity has been completed, has extended over a period of time, or still in progress.

Verb tense indicates the relationship between an action or state of being and the passage of time. The present tense indicates that something is taking place now. The past indicates that something was completed in the past. The future indicates that something will take in the future.

It means that verb tense is the changing form of verb as symbol which expresses or tells about activity or condition and statement happened in the past, present and future.

e. Add a word

Add a word has slight similar example with the term of Omission in Dulay, et al. According to Dulay et al, Omission is the absence of an item of morphemes that must appear in a sentence or utterance, e.g. They want ${ }^{\wedge}$ go to the museum. The absence preposition is to, the sentence called Omission Error of preposition to according to Dulay et al, while according to Betty S. Azzar e.g. They want ${ }^{\wedge}$ go to the museum is categorized as error $A d d$ a word, because the preposition to must be added in the sentence.

f. Omit a word

Omit a word is same as Addition in Dulay et al theory in the term of example. Betty S. Azzar gives example the error of Omit a word e.g. She entered to the university. The preposition to is not a necessary morpheme in the sentence therefore the morpheme must be omitted and it called as Error of Omit a Word. While according to Dulay et al e.g. She entered to the university is categorized as Addition Error which the preposition to considered as a morpheme that mustn't be added in the sentence.

g. Word Order

In linguistic, word order typology refers to the study of the order of the syntactic constituents of a language, and how different language can employ different orders. The error in word order e.g. I saw five times that movie. 
h. Incomplete Sentence

Incomplete sentences are missing necessary words or phrases. The incomplete sentence happens when a necessary morphemes of words or phrases is missing in a sentence or utterance.

There are causes and examples of incomplete sentences:

a. In a compound construction, a word that functions as but differs grammatically from a preceding word should not be omitted. For example,

- The car was given an oil change, and its wheels (?) aligned.

b. An incomplete sentence also results when a comparison is made completely or illogically. For example,

- My car is faster (?)

i. Spelling

Spelling rules apply to a relatively small number of words, and unfortunately almost all rules have exceptions. Nevertheless, some of the rules may help you to spell common words especially those words form with suffixes.

a. Final Silent $-\mathrm{e}$

Drop a final silent $-e$ before suffixes beginning with a vowel (ing, age, able). Keep a final silent $-e$ before suffixes beginning with a consonant (ful, ly, ness).

$$
\begin{aligned}
& \text { Hope }+ \text { ing }=\text { Hoping } \quad \text { Hope }+f u l=\text { Hopeful } \\
& \text { Dot }+ \text { age }=\text { DotageLate }+y=\text { Lately } \\
& \text { Love }+ \text { able }=\text { Loveable } \quad \text { Pale }+ \text { ness }=\text { Paleness }
\end{aligned}
$$

Learn the following exceptions: dyeing, hoeing, gluey, anful, ninth, truly, duly, wholly.

The $-e$ is retained in such words as the following in order to keep them soft sound of $c$ and $g$ : noticeable, peaceable, courageous, and outrageous. 
b. Doubling Final Consonant

When adding a suffix beginning with a vowel to words ending in one consonant proceed by one vowel (Red, Redder), notice where the word is accented. If it is accented on the last syllable or if it is a monosyllable, double the final consonant.

$$
\begin{aligned}
& \text { Prefer }+ \text { ed }=\text { Preferred } \quad \text { Benefit }+ \text { ed }=\text { Benefited } \\
& \text { Omit }+ \text { ing }=\text { Omitting } \quad \text { Profit }+i n g=\text { Profiting } \\
& \text { Occur }+ \text { ance }=\text { Occurrence } \quad \text { Differ }+ \text { ence }=\text { Difference } \\
& \text { Red }+ \text { er }=\text { Redder Travel }+e r=\text { Traveler }
\end{aligned}
$$

Note that in some words the accent shifts when the suffix is added.

Referred Reference

\section{Preferring Preference}

There are a few exceptions to this rule, like transferable and excellent, and many words that should follow the rule have alternate spellings: either worshiped or worshipped; traveling or travelling; traveler or traveler.

c. Ending in $-\mathrm{y}$

If the $-y$ is preceded by a consonant, change the $-y$ to $-I$ before any suffix except - ing.

$$
\begin{aligned}
& \text { Lady }+e s=\text { Ladies Lonely }+ \text { ness }=\text { Loneliness } \\
& \text { Try }+e d=\text { Tried Accompany }+e s=\text { Accompanies }
\end{aligned}
$$

Another example, He won the game successfully.

j. Punctuation

Punctuation can help a reader to follow the separations or links that you wish to make between sentences and parts of sentences are the same. ${ }^{61}$ According to Stanley et al., there are 12 types of punctuations. They are period (.), the question mark (?), 
the exclamation point (!), the comma (,), the semicolon (;), the colon (:), the dash (- or -$)$, the parenthesis $(())$, the brackets ([]), the ellipsis $(\ldots)$, the quotation mark $(-)$, and the apostrophe $\left(\_\right)$.

k. Capitalization

Capitalization is to capitalize the fist letter of the word. In English there are many rules for using capital letters. Notice the following table: (Alice Oshima and Ann Hogue, Introduction to Academic Writing $3^{\text {rd }}$ Edition, 2007. 7).

\section{Table 2.5 Capitalization Rules}

\begin{tabular}{|c|c|c|}
\hline No. & Rule & Example \\
\hline 1. & The first word in a sentence & My best friend is my dog. \\
\hline 2. & The Pronoun $I$ & He and I never argue. \\
\hline 3 & $\begin{array}{c}\text { Abbreviations and acronyms } \\
\text { formed from the first letters } \\
\text { of words }\end{array}$ & USA, IBM, AIDS. \\
\hline 4 & All proper nouns. & $\begin{array}{c}\text { God, New York City, Asian, } \\
\text { etc. }\end{array}$ \\
\hline
\end{tabular}

1. Article

The articles are $a$, an and the. They modify noun. $A$ and $a$ are indefinite; a car could mean any car. The is indefinite: the car indicates a specific car. The article $a$ precedes nouns that start with a consonant sound (a rocket). The article an precedes noun that start with a vowel sound (an astronaut).

m. Meaning Not Clear

Meaning not clear happens when a sentence or utterance is not interpretable, for example: He borrowed some smoke.

n. Run-On Sentence

A run-on is two complete thoughts that are run together with no adequate sign given to mark the break between them. Some 
run-ons have no punctuation at all to mark the break between the thoughts. Such run-ons are known as fused sentences: they are fused, or joined together, as if they were only one thought. It means that run-on sentence is two simple sentence joined together without a comma and without a connecting word.

\section{The Procedure of Error Analysis}

It needs some steps or stages of procedure in conducting Error Analysis. Theo Van Els, et al., states that there are some procedures in Error Analysis, namely:

a. Identification of errors. The first step in the process of analysis is recognition/identification of errors. In this step, teachers recognize the students' errors from the task given by the teachers.

b. Description of errors. The next step is describing errors; it begins when an identification stage has taken place. The description of student errors involves classification of kinds of errors made by the students.

c. Explanation of errors. The third step in the process of analysis is the explanation of error that can be regarded as a linguistic problem. This step attempts to account for how and why the students' errors occur.

d. Evaluation of errors. In this step, the teacher gives evaluation from the task done by the students depends on the task that the teacher will be giving to the students.

e. Preventing/Correcting of errors. The last step is correction of errors, the teacher checks the errors and then gives the correct one. It is done to make the students realize with their errors in order to prevent the students make the same errors later (Theo Van Els, et al., Hodder \& Stoughton, 1983. 74).

Carl James in his book —Error in Language Learning and Use: Exploring Error Analysis explains that there are five procedures in identification of errors:

a. Error detection. It's a stage which the errors are detected, so the researcher becomes aware of its presence. 
b. Locating error. The researcher locates the errors, but error location is not always so straightforward. Not all errors are easily localizable in this way. Some are diffused throughout the sentence or larger unit of the text that contains.

c. Describing error. The grammar used for describing them must be the most comprehensive we have, and the one capable of maximum = delicacy ${ }^{6}$ of descriptive detail.

d. Classiffing error. The errors are classified based on the errors classification.

e. Counting error. The last stage is counting error that the researcher counts the errors made by learner.

Gass and Selinker state that the great deal of the work on Error Analysis was carried out within the context of classroom. Therefore, there are a number of steps taken to conduct error analysis.

a. Collect data. Although this typically done with written data, oral data can also serve as a base.

b. Identify errors. What is the error (e.g., incorrect sequence of tenses, wrong verb form, singular verb form with plural subject)?

c. Classify errors. Is it an error of agreement? Or is it an error in irregular verbs?

d. Quantify errors. How many errors of agreement occur? How many irregular verb forms of errors occur?

e. Analyze source. See later discussion.

f. Remediate. Based on the kind and frequency of an error type, pedagogical intervention carried out.

Corder (in Ellis 1995: 51-52) explains the procedure of error analysis: (1) A corpus of language is selected, (2) The errors in the corpus are identified, (3) The errors are classified, (4) The errors are explained, and (5) The errors are evaluated. Error evaluation is necessary only if the purpose of the error analysis is pedagogic.

According to Corder in Ellis and Barkhuizen the procedure of Error Analysis includes the following steps:

a. Collecting a sample of learner language. Collecting a sample of 
learner language provides the data for the EA. The researcher needs to be aware that the nature of the sample that is collected may influence the nature and distribution of the errors observed.

b. Identification of Errors. The identification of errors involves a comparison between what the learner has produced and what a native speaker counterpart would produce in the same context. The basic produce is as follow:

(3). Prepare a reconstruction of the sample as this would have been produced by the learner's native speaker counterpart. (4). Assume that every utterance/sentence produced by the learner is erroneous and systematically eliminate those that an initial comparison with the native speaker sample shows to be well- formed. Those utterances/sentences remaining contain errors.

(5). Identify which parts of each learner utterance/sentence differs from the reconstructed version.

f. Description of Errors. The Description of errors is essentially a comparative process, the data being the original erroneous utterances and the reconstructed utterance. Thus, description of learner errors involves specifying how the forms produced by the learner differ from those produced by the learner's native-speaker counterparts.

g. Explanation of Errors. Explaining errors involves determining their sources in order to account for why they were made. From the point of view of SLA research this is the most important stage in an EA.

h. Error Evaluation. It involves determining the gravity of different errors with a view to deciding which ones should receive instruction.

Based on the detail explanation of the procedure of EA above it can be summed up that actually in the procedure of EA has the same stages to conduct, firstly is collecting the data, next the data is identified to find the errors made by students, thirdly the researcher describes error based on the error classifications and then she/he explains the sources the students' error and the last stage the errors 
are counted to get the total of errors made by students as evaluation. In her study, the writer chooses the procedure of EA which identified by Corder cited in Ellis and Barkhuizen to conduct the research.

\section{Methods}

This study belongs to descriptive study because it describes the errors made by the students descriptively. The data of this study is the students' Grammatical Error and the source of the data is the second semester students' assignment of their paragraph based writing Course. The materials used for analysis were the writings' assignment from the second semester of English Department students at UIN Walisongo Semarang. The students were asked to write the paragraph of writing as their final assignment for paragraph based writing Class. This study is a descriptive since it just collecting data and analyzing the paragraph writing. The data draw a conclusion based on the data, without taking general conclusion. (Hadi, 1993) another statement the aim of descriptive research is describing the data research systematically, factually, and accurately about the fact and the characteristic of population or specific area (Suryabrata: 2003).

\section{The Technique of Data Analysis}

The writer used qualitative research in her study which the method is conveyed in descriptive analysis way to describe and to interpret the result of qualitative data. To get the qualitative result, the data will be calculated and drew up in the table of percentage which the formula as follows:

$\mathrm{P}=$ Percentage

$\mathrm{F}=$ Frequency of error occurred

$\mathrm{N}=$ Number of cases (total frequent / total individual)

After reading the students' paragraph writing, the writer identified, classified and recorded the grammatical errors made by students. The various range of grammatical errors made by the students and the complexity of the errors made the writer categorize 
and subdivide them. The categories chosen are created by Dulay et all (1982:150). The categories of errors are divided into errors categories of omission, addition, misinformation and misordering.

\section{The Procedure of Research}

Conducting research needs a process or some steps. The writer did some procedures to conduct her research as a process. The procedures are elaborated below:

a. The writer needs to collect the data. Therefore before conducting the research she already prepared an instrument or a final assignment for the students. The instrument consists of instruction to compose a good writing.

b. The writer did her research in the remedial class of second semester, she took the subject data from remedial class and as the data she took from the final assignment if the students. After explaining the material, the writer gave instruction and guidelines how to do the writing final assignment.

c. Next, she collected the students' writings final assignment and checking it by circling the wrong words or sentences and returning it to the students to correct their writing by themselves.

d. Then, the students' writings were collected again and the writer checked it once more to find whether the students could correct the words or not, if students could correct it that means he/she did a mistake and vice versa means he/she did an error and then she identified the errors.

e. Next, the writer analyzed the writing of final assignment to find the most common grammatical errors made by students based on Dulay's classification of errors.

f. She calculated the total errors by drawing it up in a table based on the classification of errors then she made the result of total errors into percentages and charts.

g. The writer analyzed and classifying the sources of errors based on Brown's theory and then she explained the sources of errors made by the students. The total number of the sources of errors is drawn up in a table and converted into percentages and chart. 
h. Then she interpreted all of the data descriptively.

i. The last step was she made conclusion of her research.

\section{Findings}

\section{The Description and Analysis of Grammatical Errors}

The writer has identified the students' error and she has calculated the number of each error. She draws up the result of calculation into table and converting them into percentages. Then, she makes a pie chart based on the result. After that, she interprets the data after processing the result. This table below is the recapitulation of the students' writing errors.

The description and the analysis of data are as follow:

1. There are four types of error categories the writer found which are Omission, Addition Misinformation and Misordering. We can see the kind of error categories in the table below:

\section{Table 4.1. Error Types}

\begin{tabular}{|c|c|c|c|}
\hline No. & Error Types & Linguistic Description & $\begin{array}{c}\text { Num- } \\
\text { ber }\end{array}$ \\
\hline 1. & Omission & Missing verb, adverb, article & 6 \\
\hline 2. & Addition & Verb, adverb, be, relative that & 4 \\
\hline 3. & Misinformation & Tense, article, noun, modal, be & 21 \\
\hline 4. & Misordering & $\begin{array}{c}\text { Confusing construction, } \\
\text { phrase }\end{array}$ & 12 \\
\hline
\end{tabular}

\section{Error Types}

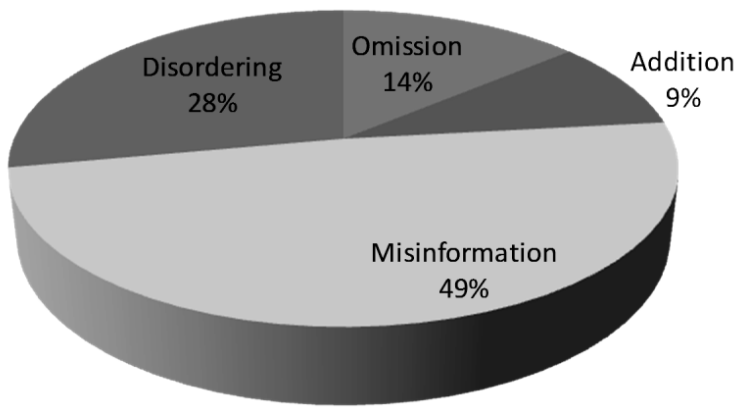


The writer used Dulay, Burt, and Kashen's theories to describe the types of error which are Omission, Addition, Misinformation, and Misordering. The writer found 43 errors from the students' writing because of omission, addition, disordering and misinformation which are 6 omissions, 4 additions, 21 misinformation and 12 disordering. Most of them are error in misinformation and another is disordering. The classifications of Error Types are as follow:

Table 4.2 The Classification of Error Types

The Error Type of Omission

\begin{tabular}{|c|c|c|c|}
\hline No & $\begin{array}{l}\text { Linguistic } \\
\text { Description }\end{array}$ & $\begin{array}{l}\text { The Grammatical Er- } \\
\text { ror }\end{array}$ & $\begin{array}{l}\text { Corrected Sen- } \\
\text { tences }\end{array}$ \\
\hline 1 & $\begin{array}{l}\text { Missing } \\
\text { Subject }\end{array}$ & $\begin{array}{l}\text { 1. And suddenly heavy } \\
\text { rain }\end{array}$ & $\begin{array}{l}\text { And suddenly It } \\
\text { was heavy rain }\end{array}$ \\
\hline 2 & Missing verb & $\begin{array}{l}\text { 2. The quality of a good } \\
\text { English course ..... } \\
\text { 3. Many advantages of } \\
\text { learning a foreign lan- } \\
\text { guage ...... }\end{array}$ & \\
\hline 3 & $\begin{array}{l}\text { Missing } \\
\text { adverb }\end{array}$ & $\begin{array}{l}\text { 4. First, we can easy to } \\
\text { get friend in other our } \\
\text { country }\end{array}$ & $\begin{array}{l}\text { First, we can eas- } \\
\text { ily to get friend in } \\
\text { other our country }\end{array}$ \\
\hline 4 & Missing be & $\begin{array}{l}\text { 5. Next, you can famous } \\
\text { 6. The weather not good }\end{array}$ & $\begin{array}{l}\text { Next, you can be } \\
\text { famous } \\
\text { The weather was } \\
\text { not good }\end{array}$ \\
\hline 5 & $\begin{array}{l}\text { Missing } \\
\text { Article }\end{array}$ & $\begin{array}{l}\text { 7. now she is to be In- } \\
\text { ternational actress }\end{array}$ & $\begin{array}{l}\text { now she is to be } \\
\text { an International } \\
\text { actress }\end{array}$ \\
\hline
\end{tabular}


The Grammatical Errors on The Paragraph Writings

\begin{tabular}{|l|l|l|l|}
\hline No & $\begin{array}{l}\text { Linguistic } \\
\text { Description }\end{array}$ & $\begin{array}{l}\text { The Grammatical Er- } \\
\text { ror }\end{array}$ & $\begin{array}{l}\text { Corrected Sen- } \\
\text { tences }\end{array}$ \\
\hline 6 & Missing 's' & $\begin{array}{l}\text { 8.It make easy us easy to } \\
\text { get informations } \\
\text { 9. The boy who sit on } \\
\text { his father and the second } \\
\text { one is the girl who wears } \\
\text { a pink veil } \\
10 . \text { She sit on a wheel } \\
\text { chair }\end{array}$ & $\begin{array}{l}\text { It makes us easy us } \\
\text { easy to get informa- } \\
\text { tion } \\
\text { The boy who sits } \\
\text { on father and } \\
\text { the second one is } \\
\text { the girl who wears a } \\
\text { pink veil } \\
\text { She sits on a wheel } \\
\text { chair }\end{array}$ \\
\hline 7 & $\begin{array}{l}\text { Missing's' as } \\
\text { a plural }\end{array}$ & $\begin{array}{l}\text { 11.We visited many } \\
\text { beach }\end{array}$ & $\begin{array}{l}\text { We visited many } \\
\text { beaches }\end{array}$ \\
\hline
\end{tabular}

The Error Type of Addition

\begin{tabular}{|c|c|c|c|}
\hline No & $\begin{array}{c}\text { Linguistic } \\
\text { Descrip- } \\
\text { tion }\end{array}$ & $\begin{array}{c}\text { The Grammatical } \\
\text { Error }\end{array}$ & $\begin{array}{c}\text { Corrected Sen- } \\
\text { tences }\end{array}$ \\
\hline 1 & $\begin{array}{c}\text { Addition } \\
\text { of be }\end{array}$ & $\begin{array}{c}\text { Second, we are be able } \\
\text { to communicate with } \\
\text { foreign people. }\end{array}$ & $\begin{array}{c}\text { Second, we are } \\
\text { able to communi- } \\
\text { cate with foreign } \\
\text { people. }\end{array}$ \\
\hline 2 & $\begin{array}{c}\text { Addition } \\
\text { of adverb }\end{array}$ & $\begin{array}{c}\text { studying during at } \\
\text { night that's better. }\end{array}$ & $\begin{array}{c}\text { Studying at night } \\
\text { is better than at } \\
\text { night }\end{array}$ \\
\hline 3 & Double \\
verb & $\begin{array}{c}\text { She does not studies at } \\
\text { night }\end{array}$ & $\begin{array}{c}\text { She does not see } \\
\text { at night }\end{array}$ \\
\hline
\end{tabular}


The Error Type of Misinformation

\begin{tabular}{|c|c|c|c|}
\hline No & $\begin{array}{l}\text { Linguistic } \\
\text { Description }\end{array}$ & $\begin{array}{c}\text { The Grammatical } \\
\text { Error }\end{array}$ & $\begin{array}{l}\text { Corrected Sen- } \\
\text { tences }\end{array}$ \\
\hline 1 & $\begin{array}{l}\text { wrong struc- } \\
\text { ture of V2 }\end{array}$ & $\begin{array}{l}\text { 1. Last week, We go } \\
\text { to Wonosari by car. } \\
2 \text {.We seen together } \\
\text { the sunset }\end{array}$ & $\begin{array}{l}\text { Last week, We } \\
\text { went to Wonosari } \\
\text { by car } \\
\text { We saw together } \\
\text { the sunset }\end{array}$ \\
\hline 2 & $\begin{array}{l}\text { wrong in } \\
\text { choosing the } \\
\text { article }\end{array}$ & $\begin{array}{l}\text { 3.Mangosteen is an } \\
\text { unique fruit } \\
\text { 4.English language } \\
\text { is a international } \\
\text { language }\end{array}$ & $\begin{array}{l}\text { Mangosteen is a } \\
\text { unique fruit } \\
\text { English language } \\
\text { is an international } \\
\text { language }\end{array}$ \\
\hline 3 & $\begin{array}{l}\text { Misinforma- } \\
\text { tion, the use } \\
\text { of the wrong } \\
\text { from the } \\
\text { structure } \\
\text {-subject-verb } \\
\text { agreement } \\
\text { and } \\
\text {-adverb }\end{array}$ & $\begin{array}{l}\text { 5. First, the teacher } \\
\text { have to delivered } \\
\text { the explanation by } \\
\text { clearly . } \\
6 . \text { Second, } \\
\text {............... not } \\
\text { many people has } \\
\text { capabilities like that } \\
\text { 7. Some problems } \\
\text { of them is caused } \\
\text { by several factors } \\
\text { Some of them has } \\
\text { assume that English } \\
\text { is a hard subject to } \\
\text { be studied }\end{array}$ & $\begin{array}{l}\text { First, the teacher } \\
\text { has to deliver the } \\
\text { explanation clearly } \\
\text {-People have ....... }\end{array}$ \\
\hline 4 & $\begin{array}{l}\text { word choice } \\
\text { must be noun } \\
\text { (verb change } \\
\text { into noun) }\end{array}$ & $\begin{array}{l}\text { 8. As we know that } \\
\text { language is a tool to } \\
\text { communicate. }\end{array}$ & $\begin{array}{l}\text { As we know that } \\
\text { language is a tool } \\
\text { of communication }\end{array}$ \\
\hline
\end{tabular}


The Grammatical Errors on The Paragraph Writings

\begin{tabular}{|c|c|c|c|}
\hline No & $\begin{array}{l}\text { Linguistic } \\
\text { Description }\end{array}$ & $\begin{array}{c}\text { The Grammatical } \\
\text { Error }\end{array}$ & $\begin{array}{l}\text { Corrected Sen- } \\
\text { tences }\end{array}$ \\
\hline 5 & $\begin{array}{l}\text { word choice } \\
\text { or diction }\end{array}$ & $\begin{array}{l}\text { 9. We can open } \\
\text { the world with our } \\
\text { ability of foreign } \\
\text { language. } \\
\text { 10.I can be easy } \\
\text { to understand the } \\
\text { material. And the } \\
\text { result when getting } \\
\text { examination I can } \\
\text { pass it. } \\
11 . \text { I did not need } \\
\text { crowded place and } \\
\text { crowded situation } \\
\text { so I need silent } \\
\text { place to get much } \\
\text { inspiration. }\end{array}$ & $\begin{array}{l}\text { We can widen our } \\
\text { horizons. } \\
\text { I can understand } \\
\text { the lecture easily } \\
\text { and absolutely/ } \\
\text { automatically I } \\
\text { will get the good } \\
\text { score). } \\
\text { I don't like the } \\
\text { crowded situation } \\
\text { when I study, in } \\
\text { order that I will } \\
\text { get some inspira- } \\
\text { tion. } \\
\text { I prefer studying at } \\
\text { night } \\
\text { Studying at night is } \\
\text { better }\end{array}$ \\
\hline 6 & $\begin{array}{l}\text { After } \\
\text { Modal must } \\
\text { be followed } \\
\text { by V1 (main } \\
\text { verb). } \\
\end{array}$ & $\begin{array}{l}\text { 14.We can learning } \\
\text { all about English . } \\
\text { Mostly happened on } \\
\text { students' writing }\end{array}$ & $\begin{array}{c}\text { We can learn } \\
\ldots . . . \ldots \ldots\end{array}$ \\
\hline 7 & $\begin{array}{l}\text { Wrong in us- } \\
\text { ing Passive } \\
\text { Must be } \\
\text { changed into } \\
\text { Correct Pas- } \\
\text { sive Sentence }\end{array}$ & $\begin{array}{l}\text { 15.the types of } \\
\text { Preposition that are } \\
\text { often make students } \\
\text { incorrect }\end{array}$ & $\begin{array}{l}\text { The types of } \\
\text { Preposition that } \\
\text { are often made by } \\
\text { students incor- } \\
\text { rectly }\end{array}$ \\
\hline
\end{tabular}


The Error Type of Misordering

\begin{tabular}{|c|c|c|}
\hline No & The Grammatical Error & Corrected Sentences \\
\hline 1 & $\begin{array}{l}\text { Many advantages can we get } \\
\text { for it }\end{array}$ & $\begin{array}{l}\text { Many advantages we can get } \\
\text { from it }\end{array}$ \\
\hline 2 & $\begin{array}{l}\text { Some students have best } \\
\text { time for studying. in the } \\
\text { morning, afternoon, at } \\
\text { night, or together while oth- } \\
\text { er people depend on which } \\
\text { one they are most comfort } \\
\text { to studying. }\end{array}$ & $\begin{array}{l}\text { Each student has own best } \\
\text { time for studying (ideal } \\
\text { study time) whereas in the } \\
\text { morning, afternoon or at } \\
\text { night. }\end{array}$ \\
\hline 3 & $\begin{array}{l}\text { When there is someone } \\
\text { gives me question which one } \\
\text { I must be choosing between } \\
\text { studying during the day } \\
\text { while other people or study- } \\
\text { ing at night. }\end{array}$ & $\begin{array}{l}\text { When there is someone } \\
\text { gives me question which } \\
\text { one I must chose between } \\
\text { studying during the day or } \\
\text { studying at night. }\end{array}$ \\
\hline 4 & $\begin{array}{l}\text { The first reason is why I study } \\
\text { at night because I will be easy } \\
\text { to get focus }\end{array}$ & $\begin{array}{l}\text { The first reason why I prefer } \\
\text { to study at night is because } \\
\text { I will focus to learn anything } \\
\text { very well }\end{array}$ \\
\hline 5 & $\begin{array}{l}\text { I can be easy to understand } \\
\text { the material. And the result } \\
\text { when getting examination I } \\
\text { can pass it }\end{array}$ & $\begin{array}{l}\text { I can understand the lec- } \\
\text { ture easily and absolutely / } \\
\text { automatically I will get the } \\
\text { good score. }\end{array}$ \\
\hline 6 & $\begin{array}{l}\text { When I study during the day } \\
\text { while other people that's hard } \\
\text { to be focus and understand } \\
\text { because everyone disturbs me }\end{array}$ & $\begin{array}{l}\text { It is hard for me to study dur- } \\
\text { ing the day, because I can not } \\
\text { concrete to learn the lecture. } \\
\text { I will not focus on my lecture } \\
\text { if I study during the day } \\
\text { which some friends prefer } \\
\text { to and It is hard for me to } \\
\text { study which is crowded and } \\
\text { uncomfortable time. }\end{array}$ \\
\hline
\end{tabular}


Based on the result of the research findings whole have been analyzed and the discussions which have been presented above, the writer generally conclude that there are four kinds of errors which are omission, addition, misinformation and misordering. The writer found 11 omissions, 3 additions, 15 misinformation and 6 misordering. It can be concluded that mostly the students had grammatical error on their writing in misinformation error $43 \%$. The writer also found the factors of error are interlingual transfer and intralingual transfer.

It can be concluded that most students of intermediate level made Grammatical Error in Omission and Misinformation of their paragraph writing as Dulaay at.all (1982) said that Omission of to be is common error made by students. Even tough those sentences appear without to be, article or preposition and still have meaning, student must use the Grammar correctly or accurately in writing. Most students made grammatical error in using modal, for example of error in misinformatiom "We can learning all about English, after modal must be followed by main verb. It mostly happened on students' writing .

\section{Conclusions}

Based on the data in the previous chapter, the writer would like to draw a conclusion that The writer found 35 errors from the students' writing because of omission, addition, disordering and misinformation which are 11 omissions, 3 additions, 15 misinformation and 6 disordering. Most of them are error in omission and another is misinformation. The students of remedial class still made some errors in paragraph writing. The most common types of errors made by students are misinformation with the number of errors is 15 or $43 \%$, omission with the number of error is 11 or $31 \%$. The writer used Dulay, Burt, and Kashen's theories to describe the types of error which are Omission, Addition, Misinformation, and Misordering. In other hand, the factors of error can be divided into interlingual transfer and intralingual transfer.

Based on the result of the research findings whole have been analyzed and the discussions which have been presented above, the 
writer generally conclude that there are four kinds of errors which are omission, addition, misinformation and misordering. The writer found 11 omissions, 3 additions, 15 misinformation and 6 misordering. It can be concluded that mostly the students had grammatical error on their writing in misinformation error $43 \%$. The writer also found the factors of error are interlingual transfer and intralingual transfer.

It can be concluded that most students of intermediate level made Grammatical Error in Omission and Misinformation of their paragraph writing as Dulaay at.all (1982) said that Omission of to be is common error made by students. Even tough those sentences appear without to be, article or preposition and still have meaning, student must use the Grammar correctly or accurately in writing. Most students made grammatical error in using modal, for example of error in misinformatiom "We can learning all about English, after modal must be followed by main verb. It mostly happened on students' writing .

After she carried out the research, she would like to give suggestion related to this result of research. Hopefully it can be applied easily in teaching learning activity and decrease the errors.

1. The lecturer should have brainstorming as warming-up before she starts teaching learning in classroom in order to make the students happy and relax. It also can help the students to switch their concentration from the previous class-subject to focus on the material.

2. The lecturer should create an impressing teaching writing technique which can catch the students' attention toward English writing activity.

3. Writing has some rules and text types. Therefore the lecturer should simplify the explanation without less the substance of material given.

4. The lecturer should give feedback toward the students' writing and communicating their progress in writing.

5. Writing is a skill which needs a process and practice. Therefore, the students should practice writing started from the simplest one such as writing a daily activity or writing their past experi- 
ence like recount text.

6. The lecturer must drill the students and emphasize the grammatical errors need to be exposed to the students in order that they can apply the grammar rule correctly in their writing.

7. The students must pay attention to the dictions or word choices, the structure of subject-verb agreement, modal auxiliaries, to be in their writing, in order that the errors made will be minimized. 


\section{REFERENCES}

Azar, Betty Schranpfer. 1989. Understanding and Using English Grammar. Jersey New. Prentice-Hall inc.

Brown, Douglas H. 2000. Prenciple of Language and Teaching, addision Wesley: Longman.

Carl James. 1998. Errors in Language Learning and Use: Exploring Error Analysis. London: Longman.

Coder, Spit. 1981. Error Analysis and Interlanguage. Oxford University press. Oxford

Dullay, Heidi. 1983. Language Two. Oxford University Press. New York

Ellis, Rod. 1997. Second Language Acquisition. Oxford University Press, New York

Ellis, Rod and Barkhuizen gary. 2008. Analysing Learner Language. Oxford University Press. China

Frances Gorbet. 1979. To Err is Human`: Error Analysis and Child Language Acquisition, English Language Teaching Journal, XXXIV.

Harmer, Jeremy. 1983. The practice of English Language Teaching. Longman. USA

Hewings, Martin. 2002. Advanced Grammar in Use. Cambridge: Cambridge University Press. 
Hubbard, Petter. 1983. A Training Course for TEFL. Oxford University Press. New York.

John Norrish. 1983. Language Learners and Their Errors,London: Macmillan Press.

Nirmala, Deli. 2009. Kesalahan Gramatical Abstrak Tesis. Issued in kajian Sastra Journal.

Norris, John. 1983. Language Learner and Their Errors. Macmillan: New York.

Richards, Jack C. 1974. Error Analysis. Perspectives on Second Language Acquisition. London: Longman Group.

Rod Ellis and Gary Barkhuizen. 2008. Analysing Learner Langaue. Oxford: Oxford University Press.

Subroto, D.E. 1992, Pengantar Metode Penelitian Lingusitik. Surakarta: UMS Press

Swan, Michael .(1995). Practical Englsih Usage. Oxford University Press. England

Thomson, A.J and Martinet, A.V. (1995). A Practical English Grammar. Oxford University Press. England 